\title{
A Tension in the Political Thought of Huey P. Newton
}

\author{
Joshua Anderson \\ Draft; do not cite \\ Final version of record: Journal of African American Studies 16(2): 249-267 (2012) \\ Available at: \\ https://link.springer.com/article/10.1007/s12111-011-9207-9 \\ DOI: $10.1007 / \mathrm{s} 12111-011-9207-9$
}

\begin{abstract}
This article is a discussion of the political thought of Huey P. Newton, and by extension the theory and practice of the Black Panther Party. More specifically, this article will explore a tension that exists between Newton's theory of Intercommunalism and the Black Panther Party Platform. To that end, in section 1, there is a discussion of the ideological development of the Black Panther Party, which culminated in Newton's theory of Intercommunalism. In section 2, there is a presentation of the Black Panther Party Platform, and the activities of the Black Panther Party, in particular the survival programs. Section 3, discusses several ways in which there seems to be a conflict between Newton's ideology and his political practice. While some are only apparent contradictions, there does remain a deep conflict between the dialectical basis of Intercommunalism and the foundational basis of the Party Platform.
\end{abstract}

Huey P. Newton, founder of the Black Panther Party, is perhaps one of the most intriguing American intellectuals of the last half of the $20^{\text {th }}$ century. Despite this fact, his thought has been given little critical scrutiny. This article seeks to remedy that situation by discussing a deep tension that exists between the ideology of the Black Panther Party and their practical activity. ${ }^{1}$ This article actually serves two purposes. First, this article seeks to simply bring a voice to the table that this writer believes has too long been ignored. It has now been over forty years since the founding of the Black Panther Party, providing some critical distance between, by all accounts, Newton's bigger-than-life

\footnotetext{
${ }^{1}$ Throughout this paper I will be referring to both Newton's political thought, and the ideology and practices of the Black Panther Party. Since Newton was the co-founder, and chief theoretician, of the Black Panther Party, I take it for granted that these are roughly the same thing. So, Newton's ideological views are basically the ideological views of the Black Panther Party, and the principles and practices of the Black Panther Party are positions that Newton would or did endorse and thus can be considered part of his overall political position.
} 
personality ${ }^{2}$ and Newton's thought. Further, the last decade, or so, has seen an increase in literature on Newton, but little of it has looked critically and philosophically at Newton's thought itself. ${ }^{3}$ The other aim is to discuss the aforementioned tension.

"Newton was, without a doubt, the most forceful, best-known and most ambitious theorist-practitioner of the Black Power Movement.” (McCartney 1992, 133) Newton's genius rested in his ability to amalgamate and synthesize others' thinking, and then to reinterpret and make these ideas relevant to the situation that existed in the United States in his time. This reinterpretation and re-appropriation extends from the Black Panther symbol itself, which was taken from the Lowndes County Freedom Organization $^{4}$ to identifying the lumpenproletariat as the new revolutionary class-an idea Newton took from the work of Franz Fanon ${ }^{5}$ - to the Black Panther Party Platform, which bears striking resemblance to the "Muslim Program" of Elijah Muhammad's Nation of Islam, ${ }^{6}$ not to mention Newton's extension of Marxist-Leninist thinking to conditions in the United States.

The article will progress in the following way: I begin by presenting the development of Newton's political ideology, and then discussing the basic political principles and practices of Newton and the Black Panther Party. This leads to the identification of a deep tension in Newton's overall political views. The tension manifests in various ways, and while some of these can be adequately dealt with, the

\footnotetext{
${ }^{2}$ See for example Hilliard, et al (2006), Pearson (1996) and Seale (1991).

${ }^{3}$ Jeffries (2003) is a notable exception.

${ }^{4}$ See Jeffries (2003) and Pearson (1996).

${ }^{5}$ See Jeffries (2003) and Seale (1991).

${ }^{6}$ See Newton (1996) and Muhammad (1974) for a comparison of the Black Panther Party Platform and the Nation of Islam's Muslim Program.
} 
conflict between Newton's and the Black Panther Party's official ideology and their basic political principles and practices cannot be completely resolved.

Before continuing, it should be noted that I am predominately concerned with Newton's political thought as it developed between 1966 and 1972. These two dates are important because they represent not only Newton's most productive period, and the time when the Black Panther Party was most active, but also these are the years in which Newton originally laid out the Black Panther Party Ten-Point Platform and Program, in 1966, and when he adjusted it, in $1972^{7}$ — the Ten-Point Platform being the basic political principles of Newton and the Black Panther Party.

\section{Newton's Developing Ideology}

Huey Newton's thought was profoundly affected by Marx, Lenin and Mao. Newton saw himself continuing the Marxist-Leninist tradition and making it relevant to the situation occurring in the United States, especially for African-Americans. ${ }^{8}$ Newton believed that "The Black Panther Party is a Marxist-Leninist Party because we [the Black Panther Party] follow the dialectical method and we also integrate theory with practice." (Newton 1995, 25)

Newton took seriously Mao's claim that "correct knowledge can be arrived at only after many repetitions of the process leading from matter to consciousness and then back to matter, that is, leading from practice to knowledge and then back to practice." (Mao 1972, 208-9) Thus, Newton's thinking went through continuous development as he was enlightened by his revolutionary practice. As Newton struggled with changing circumstances and his own intellectual maturation, he continually redefined and

\footnotetext{
${ }^{7}$ See Newton (1996) pp. 119-126.

${ }^{8}$ See especially Newton (1995; 2009), Jeffries (2003) and Seale (1991).
} 
rearticulated his position. According to Judson Jeffries (2003), Newton's thinking is marked by four distinct theoretical phases: Black Nationalism, Revolutionary Socialism, internationalism, and Intercommunalism. ${ }^{9}$

Early on, Newton believed that the solution to many of the problems that faced African-Americans could be solved by the creation of a separate nation. Newton claimed that the Black Panther Party "realized the contradictions in society, [and] some oppressed people in the past had solved some of their problems by forming nations." (Erikson \& Newton 1973, 27) Newton believed that if African-Americans truly wanted to preserve their own culture and be able to determine the course of their lives, the most reasonable solution was to create their own nation, just as other oppressed people throughout the world had. During this Black Nationalist phase, the aims and objectives of Newton and the Black Panther Party, and even many of the Party's activities, were not much different than those of other Black Nationalist movements that arose around the same time. ${ }^{10}$ All of these organizations basically held to the view that "Black Nationalism as a social theory and practice organized around the concept and conviction that Blacks are a distinct historical personality and they should, therefore, unite in order to gain the structural capacity to define, defend and develop their interests.” (Karenga 1980, 15)

However, Newton soon realized that this type of Nationalist solution was untenable. As Newton explains:

In the past, nationhood was a fairly easy thing to accomplish. If we look around now, though, we see that the world - the land space, the livable parts as we know them-is pretty well settled. So we realized that to

\footnotetext{
${ }^{9}$ For Newton's explanation of his development see Newton (1995), the essay titled Speech Delivered at Boston College: November 18, 1970. pp. 20-38.

${ }^{10}$ In particular, the Deacon's of Defense, Maulana Karenga's Us organization, and later manifestations of the Student Non-Violent Coordinating Committee. See Barbour (1968), Brisbane (1974) and McCartney (1992).
} 
create a new nation we would have to become a dominant faction in this one, and yet the fact that we did not have power was the contradiction that drove us to seek nationhood in the first place. It is an endless cycle, you see: to achieve nationhood, we needed to become a dominant force; but to become a dominant force, we needed to be a nation. (pp. 27-8)

Newton then adjusted his view of Black Nationalism to stress "race consciousness, intraracial cooperation, and the building, controlling, and maintaining of black institutions." (Jeffries 2003, 66) Newton eventually rejected even this modified form of Black Nationalism because he believed that Black Nationalism often degenerated into a vulgar cultural elitism, and did not lead to true revolutionary action or change. Newton, Bobby Seale and other Panthers often criticized Maulana Karenga's Us organization for just this type of non-revolutionary cultural elitism. ${ }^{11}$ Also, Newton saw what Karenga and others advocated in the name of Black Power as a step backward as opposed to a step forward. Newton words it thusly:

Karenga and some other nationalistic groups seem to be hung up on surviving Africanisms, or what we call cultural nationalism. Cultural nationalism deals with a return to the old culture of Africa and that we are somehow freed by identifying and returning to this culture, to the African cultural stage of the 1100's or earlier. Somehow they believe that they will be freed through identifying in this manner. (Hilliard 2007, 12)

Finally, a few practical factors may have encouraged Newton and the Black Panther Party to move away from Black Nationalism. First, the Party had hired Charles Garry, a white attorney, to defend Newton in his murder trial. Second, the Party began to ally itself with various, predominately white, radical organizations such as the Peace and Freedom Party and Students for a Democratic Society. ${ }^{12}$ Newton came to realize that while one's skin color affected how one approached the world, it did not strictly determine one's entire worldview. Further, Newton came to understand that African-

\footnotetext{
${ }^{11}$ See Newton $(1995 ; 2009)$ and Seale (1991).

12 See Hilliard, et al (2006), Newton (1996; 2009), Pearson (1996), and Seale (1991).
} 
Americans could not create a revolution alone. They would have to work with progressive and politically conscious whites for there to be any hope of progress. What the facts "on the ground" indicated to Newton was "that any notion of a black armed revolution was strictly romantic, [because ... e]ven if every black American supported a revolution, they would still be outnumbered ten to one by American whites." (Jeffries 2003, 69)

After moving away from Black Nationalism, Newton and the Black Panther Party endorsed a form of Revolutionary Socialism. Newton began to believe that racism could not be considered the most important issue. "In this phase of Panther ideology, the class struggle was given equal weight with the race struggle." (Ibid.) Newton believed that it was only by abandoning capitalism and creating a socialist society that many, or most, of the problems that faced African-Americans could be resolved. In this phase of Newton's thinking, racism, while not necessarily a result of capitalism, was reinforced and exacerbated by the capitalist structure.

"Newton argued that a basic tenet of revolutionary socialism is the principle that things people commonly use and commonly need should be commonly owned." (p. 73) Further, Newton envisioned a form of radical democracy whereby the people directly determine how those things commonly held should be distributed equitably. In other words, "the administration of the government should be subjected to the dictates of the people.” (Ibid.) Like Lenin, Newton envisioned an eventual withering away of the state.

Newton and the Black Panther Party would soon move beyond Revolutionary Socialism to an internationalist phase. According to Newton, one "cannot change a part of the whole without changing the whole, and vice versa." (Erikson \& Newton 1973, 29) 
Thus, Newton realized that the Black Panther Party "had to unite with the peoples of the world," and work in concert with other oppressed people. (Newton 1995, 31) Newton became an internationalist because he felt the Black Panther Party was fighting an internationalist oppressor-viz. the United States. Finally, "Newton argued that because of the abduction of the Africans from their homeland, blacks had been dispersed all over the world; thus blacks were by geographical circumstance internationalists." (Jeffries $2003,75)$

The internationalist phase in Newton's thought was short lived and was soon replaced by Intercommunalism. “The notion of Intercommunalism is perhaps Newton's most important theoretical contribution. It represents a higher level of revolutionary consciousness and a further development of Marxist-Leninist theory." (p. 78) Intercommunalism is based on the idea that there no longer exists, in actual fact, something that can be identified as a nation-state. For Newton, there were certain "characteristics that any people who call themselves a nation should have. These are economic independence, cultural determination, control of the political institutions, territorial integrity, and safety." (Newton 1995, 31) Because of the development of technology, the increasing influence of global capital, and because of the militaristic and intellectual hegemony of the United States, Newton felt that the United States could no longer be considered a nation but an empire. Newton pointed out that

the evidence shows very clearly that the United States is not a nation for its power transcends geographical boundaries and extends into every territory of the world. Through modern technology the United States can control the institutions of other countries. Hence, so long as it can control the political forces the cultural institutions, the economy, the resources and the military of other territories at will and for the narrow interests of a 
small clique then we cannot say that America is a nation any longer - it is an empire. ${ }^{13}$

As a result of the United States being an empire, other "nations could not exist, for they did not have the criteria for nationhood. Their self-determination has been transformed by the imperialists and the ruling circles." (Newton 1995, 31-2) What remained instead of a nation are mere communities.

Newton referred to the United States as an empire. More specifically, he felt that there is a small ruling circle of imperialists who dominate the United States, thus making it a de facto empire. The more important point is what the United States imperial status implies on a global level:

The ruling reactionary circle through the consequence of being imperialists transformed the world into what [can be called] "Reactionary Intercommunalism." They laid siege upon all the communities of the world, dominating the institutions to such an extent that the people were not served by the institutions in their own land. (p. 32)

"A central tenet of $[R]$ evolutionary $[I]$ ntercommunalism... is that 'contradiction is the ruling principle of the universe,' that everything is in a constant state of transformation." (Newton 1996, 28) Based on this view, American imperialism's creation of a "global village" - through Reactionary Intercommunalism - has laid the foundation for its own demise. Newton saw the stage being set for a transformation from Reactionary Intercommunalism to Revolutionary Intercommunalism.

The same technology and material conditions that supported the status quo-i.e., Reactionary Intercommunalism and the ruling elites' imperial ambitions-would "allow the people of the world to develop a culture that is essentially human and would nurture

\footnotetext{
${ }^{13}$ Newton, Huey. Intercommunalism: A Higher Level of Consciousness quoted in Jeffries $(2003,79)$.
} 
those things that would allow the people to resolve contradictions in a way that would not cause the mutual slaughter of all of us." (Newton 2002, 187)

To step back, what existed, according to Newton, was a collection of interconnected communities, and a "community by way of definition is a comprehensive collection of institutions which serve the people who live there." (Newton 1995, 32) In Reactionary Intercommunalism, the ruling elite commandeer the institutions and use them for their own ends as opposed to those of the people within the community. What Revolutionary Intercommunalism claims is

that the struggle in the world today is between the small circle that administers and profits from the empire of the United States, and the peoples of the world... [who] want to determine their own destinies... [Therefore, $t$ ] he people of the world... must seize power from the small ruling circle and expropriate the expropriators, pull them down from their pinnacle and make them equals, and distribute the fruits of our labor that have been denied us in some equitable way. (Newton 2002, 187-8)

What remains to be done is that the people of the world must take control of the means of production and all social institutions. Then, "there will be a qualitative leap and a change in the organization of society." (Ibid.) This change in society represents the essence of Revolutionary Intercommunalism.

Newton's ultimate goal, based on his Marxist-Leninist influences, was to have a stateless society. However, Reactionary Intercommunalism and American imperialism had already created this stateless society. Revolutionary Intercommunalism takes the next logical step by pushing for a more egalitarian society and the abolition of divisive class distinction. (Jeffries 2003, 80) It is at this point that Newton becomes his most idealistic. He believed that all disenfranchised communities should be acting together for the benefit of all. "Therefore, self-centeredness... is de-emphasized in favor of a 
consciousness that stresses the group's awareness of its relationship and commitment to the larger worldwide oppressed community." (Ibid.)

So, Intercommunalism for Newton arose out of two factors. The first is intellectual — for lack of a better term — and is based on Newton's understanding of Marx and dialectical materialism. The second factor is historical/sociological, and that is the rise of American imperialism. American imperialism had made the possibility of a nation impossible, thus leaving behind a collection of interconnected communities dominated by a small group of ruling elites who control the institutions of the various communities. The upshot of the development to this point is that it has created abundant wealth and incredible advances in technology. However, Newton felt that, at some point, the oppressed groups in these communities would seize the means of production and displace the elites, using the technological advances et cetera of the Imperial/Reactionary Intercommunal structure. Revolutionary Intercommunalism will then have occurred-or more correctly be occurring - at the point when the people control their own destinies and redistribute the wealth, produce, goods and services of the interconnected communities in an equitable and egalitarian fashion.

For Newton, then, the historical reality was a situation in which an imperial power-namely, the United States-was such a dominating force in the world that there no longer existed anything that could rightly be called a nation. What existed instead was the state of Reactionary Intercommunalism "because the world is now integrated into one community." (Newton 2002, 188) All that needed to be done was that oppressed and alienated groups must - using the same technologies and forces that currently are held by 
a small circle of ruling elites - seize the means of production and bring about a state of

Revolutionary Intercommunalism.

\section{The Political Principles and Practices of the Black Panther Party}

As with any political activist, particularly one aligned with a political organization, there is more than just a governing ideology. This is all the more true for a self-described Marxist like Newton who certainly had to take seriously Marx's claim that: "The philosophers have only interpreted the world in various ways; the point is to change it." (Marx \& Engels 1998, 571) Indeed, for Newton there was both the governing ideology which moved from Black Nationalism to Intercommunalism, and the basic principles and practices of the Black Panther Party which were manifested as what I will be broadly construing as the Party Platform. It is to the Platform that I now turn. Following a brief overview of the Ten-Point Platform and survival programs ${ }^{14}$ I will, in the next section, discuss the tension that exists between the Platform and Newton's theory of Intercommunalism.

Though Huey Newton and Bobby Seale-the co-founders of the Black Panther Party - had belonged to or been involved with several other organizations ${ }^{15}$, their "ideas of self-defense estranged them from [such] organizations." (Hilliard, et al 2006, 26) During this time Newton began voraciously reading the speeches of Malcolm X, Che Guevara's Guerilla Warfare, the writings of Mao Tsetung, and, perhaps most importantly, Robert Williams' Negroes With Guns. ${ }^{16}$ Not long after this, in the fall of

\footnotetext{
14 Throughout this article, and especially in this portion, the Party Platform and the survival programs will be discussed as two fundamentally linked concepts. Therefore, for ease of reading, I will refer to both simply as the Party Platform, or simply just "the Platform", unless otherwise specified.

${ }^{15}$ Most importantly several organizations at Oakland City College where both Newton and Seale were parttime students including the Afro-American Association, Revolutionary Action Movement, and the Soul Students Advisory Council. See Newton (2009), Hilliard, et al (2006), Pearson (1996) and Seale (1991). ${ }^{16}$ See Newton (2009), Hilliard, et al (2006) and Seale (1991).
} 
1966, Newton and Seale sat down and put forth something that was a combination of a Bill of Rights and a Declaration of Independence. After some minor revisions, mostly grammatical, from Newton's brother Melvin Newton, Huey Newton and Bobby Seale began to make copies and distribute their Bill of Rights cum Declaration of Independence as "The Black Panther Party for Self-Defense Ten-Point Platform and Program". ${ }^{17}$

At this point in the Party's development, Newton considered himself a Black Nationalist and the Black Panther Party a Black Nationalist organization, and the Platform reflects this. The Platform called for self-determination, employment, decent housing, exemption from military service, and systemic changes in the criminal justice and economic systems of the United States. ${ }^{18}$ Yet, as the overarching ideology of the Black Panther Party changed over time, from Black Nationalism to Intercommunalism, it would seem natural that the Platform would conflict with the newer ideologies.

Newton was not completely unaware of these conflicts. ${ }^{19}$ Thus, Newton reworded some of the points in the Platform. For example, the 1966 formulation of Point 7 reads:

We Want An Immediate End To Police Brutality And Murder of Black People.

We believe we can end police brutality in our Black community by organizing Black self-defense groups that are dedicated to defending our Black community from racist police oppression and brutality. The Second Amendment to the Constitution of the United States gives a right to bear

\footnotetext{
${ }^{17}$ See Newton (2009), Hilliard, et al (2006) and Seale (1991).

${ }^{18}$ See Newton (1996) pp. 119-22.

${ }^{19}$ As will be seen in the following discussion, the changes Newton made to the Party Platform do not really resolve the tension that exists between the basic principles of The Black Panther Party's political practice and the new Intercommunalist ideology. Newton had basically settled on Intercommunalism by the time he had his conversations with Erik Erikson at Yale in 1971, see Erikson \& Newton (1973) and Hilliard \& Weise (2002) pp. 181-199. Since the revisions to the Platform occurred in 1972, see Newton (1996) pp. 123-126, there is little reason to think that Newton, or the Panthers, ever gave up on the Platform. My thanks to an anonymous reviewer for pointing out to me that this point might not be clear from the discussion within the paper.
} 
arms. We, therefore, believe that all Black people should arm themselves for self-defense. (Newton 1996, 120-1)

The 1972 formulation was revised in light of Newton's views of socialism and Intercommunalism and thus reads:

We Want An Immediate End To Police Brutality And Murder of Black People, Other People Of Color, All Oppressed People Inside The United States.

We believe that the racist and fascist government of the United States uses its domestic enforcement agencies to carry out its program of oppression against Black people, other people of color and poor people inside the United States. We believe it is our right, therefore, to defend ourselves against such armed forces and that all Black and oppressed people should be armed for self-defense of our homes and communities against these fascist police forces. (pp. 124-5)

One can see how Newton tried to deal with the developing ideology of the Party and how it related to the Party Platform. First, Newton expanded the circle of those about whom the Party was concerned. African-Americans could still be seen as of primary concern for the Party in the 1972 formulation. However, African-Americans were not the only community which the Party either sought to benefit, or, at the very least, saw as having some solidarity. Further, the 1972 formulation also has a slightly more nuanced understanding of oppression. The 1966 formulation refers to the constitutional right of all Americans to arm themselves as the solution to self-evident police brutality within the African-American community. The 1972 formulation, however, contends that racist and fascist tendencies within the United States government lead "domestic enforcement agencies to carry out $[\ldots]$ oppression.” (p. 125) The oppression, itself, is what gives oppressed groups the right to defend themselves.

The reformulated version of the Platform remained primarily concerned with the African-American community, even though Newton's and the Black Panther Party's 
awareness of other oppressed communities increased. Newton's and the Black Panther Party's commitment to the uplift of the African-American community perhaps blinded them to a potential conflict between the Platform and the Party's developing ideology. While it has been noted that Newton did reformulate some of the Platform, there were still aspects of the Platform that maintained the aspects of the Black Panther Party's original Black Nationalist orientation.

As an example of this lingering Black Nationalism, compare the different versions of point 3 of the Platform. The 1966 version reads as follows:

We Want An End To The Robbery By The Capitalists Of Our Black Community.

We believe that this racist government has robbed us, and now we are demanding the overdue debt of forty acres and two mules. Forty acres and two mules were promised 100 years ago as restitution for slave labor and mass murder of Black people. We will accept the payment in currency, which will be distributed to our many communities. The Germans are now aiding the Jews in Israel for the genocide of the Jewish people. The Germans murdered six million Jews. The American racist has taken part in the slaughter of over fifty million Black people; therefore, we feel that this is a modest demand that we make. (p. 119)

The 1972 version reads:

We Want An End To The Robbery By The Capitalists Of Our Black And Oppressed Communities.

We believe that this racist government has robbed us and now we are demanding the overdue debt of forty acres and two mules. Forty acres and two mules were promised 100 years ago as restitution for slave labor and mass murder of Black people. We will accept the payment in currency which will be distributed to our many communities. The American racist has taken part in the slaughter of our fifty million Black people. Therefore, we feel this is a modest demand that we make. (p. 123)

Notice, Newton did alter the "What We Want" portion of point 3 to include not just the African-American community but oppressed communities in general. However, in the 
"What We Believe" portion Newton continued to maintain that it was the racist government that owed an overdue payment of reparations that was promised to former slaves at the end of the American Civil War.

It seems odd that Newton would go to the effort of adding other oppressed communities as amongst those whom the Black Panther Party hoped to benefit, without explicating either how those oppressed communities were being robbed by "the Capitalists" or what the justification for their restitution was. The claim that the government is racist and owes restitution for past abuses, does not necessarily apply to all other oppressed communities, though a similar argument could be made regarding Native Americans, for example.

There are two sides to what I am broadly construing as "the Party Platform". There is the official Ten-Point Platform, just discussed, and also how that Platform manifested itself in the Black Panther Party's political activities and practices, particularly through its survival programs. I will not discuss any of the programs in depth. Rather, I will only suggest what the programs were, how Newton and the Black Panther Party thought about them, and what some of the programs accomplished. ${ }^{20}$ The Black Panther Party saw the survival programs as an extension of its concept of selfdefense. Newton had always felt that self-defense was more than merely one's right to defend oneself against a physical attack. It was also

self-defense against inadequate housing, failing educational systems, police brutality, [and] joblessness in [the African-American] community. So, it's important to understand that the Black Panther Party's survival programs were also a part of [its] self-defense strategy, and not just the whole imagery of the gun. (Hilliard $2007^{21}$ )

\footnotetext{
${ }^{20}$ For a more complete discussion of the purposes and successes of the survival programs see Abron (1998) and Hilliard (2009).

${ }^{21}$ DVD interview.
} 
Not only were the survival programs an extension of the Black Panther Party's understanding of self-defense, but they were also an actualization of the selfdetermination that was an integral aspect of Black Power. Kwame Ture (formerly Stokely Carmichael) and Charles Hamilton express this self-determination as follows:

[B]lack people in America must get themselves together. [Black Power] is about black people taking care of business - the business of and for black people. The stakes are really very simple: if we fail to do this, we face continued subjection to a white society that has no intention of giving up willingly or easily its position of priority and authority. If we succeed, we will exercise control over our lives, politically, economically and psychically. We will also contribute to the development of a viable larger society; in terms of ultimate social benefit, there is nothing unilateral about the movement to free black people. (Ture \& Hamilton 1992, xv)

"Institutional racism relegated a disproportionate number of African Americans to deplorable housing, poor health care services, an unresponsive criminal justice system, inadequate diets, and substandard education." (Abron 1998, 178) Newton noted an important result of these conditions - i.e. deplorable housing, poor health care, et cetera - that obtained due to institutional racism: "The masses of Black People have always been deeply entrenched and involved in the basic necessities of life. They have not had time to abstract their situation. Abstractions come only with leisure, the people have not had the luxury of leisure." (Newton 1995, 89) Because a significant proportion of the African-American community was preoccupied with maintaining the bare necessities of life, they did not have the time to reflect on the causes of their conditions, and they certainly did not have the time to do anything about their situation.

The survival programs were implemented to counteract this. "In order to fully develop the human capital of community, the day-to-day needs of the people must be addressed. Party members understood that in order to maximize one's potential, personal 
safety, nourishment, and adequate health care were paramount." (Abron 1998, 179) The Black Panther Party's survival programs, therefore, focused on human sustenance and health, but also included education and programs to deal with criminal justice issues.

The survival projects included police-alert patrols, The Black Panther Intercommunal News Service, the breakfast for children program, free medical clinics, the Oakland Community School, free busing to prisons, the free food program, the free clothing and shoe programs, the free ambulance program, sickle cell anemia testing, Seniors Against a Fearful Environment (S.A.F.E), and the free pest control program. (Ibid.)

Newton and the Black Panther Party were often criticized because, it was argued, the survival programs were inconsistent with the Black Panther Party's selfunderstanding that they were a revolutionary organization. It was claimed that the survival programs were mere reformism and not true revolutionary activity. Bobby Seale has a response, on behalf of the Black Panther Party, to just this type of criticism. Seale states:

A lot of people misunderstand the politics of these programs; some people have a tendency to call them reform programs. They're not reform programs; they're actually revolutionary community programs. A revolutionary program is one set forth by revolutionaries, by those who want to change the existing system to a better system. A reform program is set up by the existing exploitative system as an appeasing handout, to fool the people and to keep them quiet. (Seale 1991, 412-3)

There are several important things that should be noted about the survival programs. First, though they functioned as incremental steps, an argument can be made that the survival programs were in fact revolutionary activities. Second, the survival programs had a profound effect on the existing system. For example, the free breakfast programs resulted in government-funded free lunch programs, and the police patrols resulted in the establishment of a Citizen's Complaint Board to hear complaints from the community about the Oakland Police Department. The survival programs also raised 
awareness in the society at large of issues that existed, such as police brutality and the existence of hunger and poverty, within the United States, particularly for AfricanAmericans. Further, one of Newton's and the Black Panther Party's aims in instituting the survival programs was to give some relief to the African-American community so that there would be at least some time for the community to reflect on both the problems that existed for them and the causes of the situation in which they found themselves. There was also a practical upshot to the implementation of the survival programs, namely, they created a trust and endearment between the Black Panther Party-i.e. the vanguard or revolutionary cadre - and "the People". Finally, though this may not be evident from the discussion, there is a tight link between what survival programs were instituted and the stated principles of the Ten-Point Platform-e.g. the police patrols and point 7 of the Platform which calls for an end to police brutality.

\section{The Tension}

Now that there is a basic understanding of the Black Panther Party Ten-Point Platform and the survival programs, there can be a discussion of possible conflicts between the Platform and Newton's theory of Intercommunalism. There are two ways that the Platform, broadly construed, and Intercommunalism can be seen to conflict. First, the Platform can be seen to conflict with Intercommunalism in a practical way. Second, the Platform can be seen to conflict theoretically.

I will discuss the practical conflict first. Understood practically, a tension exists between Intercommunalism and the Platform because the Platform does not fit into Newton's theory of Intercommunalism. That is to say, the core principles and activities of the Party do not fit into the way Newton views the world via his theory of 
Intercommunalism. According to Newton's theory, the situation that obtained at his time, and perhaps might still obtain, was Reactionary Intercommunalism. The state of Reactionary Intercommunalism was premised on the belief that due to the United States' status as a de facto empire, there no longer existed anything that could be identified as a nation. Thus, Newton claimed that:

The ruling reactionary circle through the consequence of being imperialists transformed the world into what [can be called] "Reactionary Intercommunalism." They laid siege upon all the communities of the world, dominating the institutions to such an extent that the people were not served by the institutions in their own land. (Newton 1995, 32)

However, Newton believed that Reactionary Intercommunalism lays the foundation for a more egalitarian, and essentially communist or socialist, stateless utopia, what Newton called Revolutionary Intercommunalism. For Newton, in order to arrive at Revolutionary Intercommunalism

the people of the world... must seize power from the small ruling circle and expropriate the expropriators, pull them down from their pinnacle and make them equals, and distribute the fruits of our labor that have been denied us in some equitable way. (Newton 2002, 188)

So, once the people of the world take control of the means of production and all social institutions, then "there will be a qualitative leap and a change in the organization of society." (Ibid.)

Here, then, is the practical tension that exists between the Platform and Intercommunalism. Intercommunalism suggests the way forward is for the people of the world to overthrow the ruling elites and take control of the means of production and social institutions. The Platform, however, seems to indicate that the way forward, at least in practice, is for the African-American community to first provide for their basic needs, and then respond to particular instances of oppression. Thus, for Newton and the 
Black Panther Party, is the goal expropriating the expropriators by the people of the world, or is the goal the self-determination of the African-American community?

There are two ways that one could argue that the goal of Intercommunalism and the goal of the Platform are not practically inconsistent. First, one could argue that the goal of self-determination for the African-American community leads to the people of the world taking over the means of production and social institutions. Second, one could argue that the two goals are the same.

The state of Reactionary Intercommunalism, which is how Newton believed the world existed, left the world not as independent nation-states, but as small groups of interconnected communities. So, among these communities there were those who Newton felt were beginning to throw off the yoke of imperial oppression, such as the people of Vietnam and Cuba. However, there were other communities who were still principally dominated by the ruling reactionary elites; one of these communities was the African-American community within the United States.

Newton and the Black Panther Party were interested in the self-determination of the African-American community because they were members of the African-American community. Further, Newton believed that

[B]lack people are the vanguard of the revolution in this country, and, since no one will be free until the people of America are free, that black people are the vanguard of the world revolution. [...] Now as far as the Party is concerned, it has been exclusively black so far. [...] We have to get to the black people first because they were carrying the banner first. (Erikson \& Newton 1973, 37-8)

What Newton means here by vanguard is not quite the same as the Marxist-Leninist "revolutionary cadre" understanding of vanguard. By referring to the African-American community as the vanguard, Newton means that the African-American community is the 
beginning. Once African-Americans have self-determination, then other oppressed communities will follow suit. More accurately, the African-American community and the Black Panther Party will help other oppressed communities realize their own selfdetermination. By beginning with the African-American community Newton and the Black Panther Party "are being pragmatic in order to do the job that has to be done, and then, when that job is done, the Black Panther Party will no longer be the Black Panther Party.” (p. 43)

In order to answer the question of whether or not the Platform and Intercommunalism conflict practically, Newton can answer that self-determination for the African-American community leads to a world-wide revolution. Thus, the Platform and Intercommunalism are not inconsistent because the goal of narrowly focused selfdetermination leads to the goal of Revolutionary Intercommunalism. On this reading, not until individual communities have self-determination can the ruling imperialist circle be overthrown and the means of production and social institutions be taken over by those that are affected by them. Moreover, Newton claims that the African-American community stands in a unique position because they are one of the most oppressed communities in the United States, and Newton sees the United States as the world-wide oppressor. Further, because of the African Diaspora during the slave trade, the AfricanAmerican community "can easily identify with other people in other cultures. Because of slavery, [African-Americans] never really felt attached to the [concept of a] nation.” (p. 38)

The other way to respond to the practical conflict between the Platform and Intercommunalism is to claim that the goals of both are actually the same. In order to 
claim that the goals of the Platform and Intercommunalism are the same, one has to represent Newton's understanding in a slightly different way than was presented in order to reach the conclusion that the goals of the Platform lead to the goals of Intercommunalism.

Newton believed that Intercommunalism is not a theory, per se, though there are theoretical implications. Newton believed that "We [Newton and the Black Panther Party] are not bringing about the concept of Intercommunalism or even the fact of Intercommunalism. Reactionary Intercommunalism [...] was brought about by the ruling circles of American imperialism." (p. 73) Newton saw himself as simply describing what was occurring in the world at his time. Understood descriptively, Intercommunalism posits the fact of many interconnected communities that are dominated by a small ruling circle.

One of these interconnected communities happened to be that of AfricanAmericans. Newton and the Black Panther Party saw the African-American community "as among the victims of reactionary intercommunalism." (Ibid.) Further, according to Newton,

[a]s victims, we [Newton and the Black Panther Party] resist; as materialists, we try to understand what our situation is in respect to it. [...] We try to find out what reactionary intercommunalism is and then try to manipulate it in the people's favor. [Further,] the people of the world are manipulating it already by struggling against reactionary intercommunalism. There are battle fronts throughout Asia, Africa, Latin America, and there is turmoil in Europe now too. People are dissatisfied with the state of the world today and they are resisting. [...] And all of these struggles are against the American ruling circle in one way or another. (Ibid.)

Thus, anytime a community resists or tries to alter how that community relates to the Reactionary Intercommunal fact that community is, at least potentially, moving 
toward Revolutionary Intercommunalism and the people of the world are taking over the means of production and the social institutions that directly affect that community's existence. Because all communities are interconnected, resistance anywhere gets all communities that much closer to a society where "the people" have control over and can determine their own existence.

Newton felt that one could not talk about the struggle of African-Americans without at the same time talking about the struggles elsewhere in the world, and vice versa. (pp. 73-4) Therefore, if the goal of the Platform is self-determination for the African-American community, and because American imperialism has made all communities interconnected; then, the self-determination of the African-American community means that all communities have, in some sense, taken a bit more control of the social institutions that affect them, or at least have made the oppressive ruling elite that much less dominating.

Another way of wording the claim that the goals of the Platform and Intercommunalism are the same is to suggest that the people of the world taking over the means of production and social institutions from the circle of ruling elites-the goal of Intercommunalism - is just another way of saying that the people of the world have selfdetermination. So, if the African-American community has self-determination-the goal of the Platform - and because all communities are interconnected, then all people have at least somewhat more self-determination.

I have suggested two different responses to the practical tension, which is really only an apparent contradiction and not truly a problem for Newton. One can respond that the goal of the Platform - self-determination of the African-American community-leads 
to the goal of Intercommunalism - the people of the world taking over the means of production and control of the social institutions that affect their lives. One can also respond that the goals of the Platform and Intercommunalism are actually the same. Ultimately, however, it may be that the two responses are really not that different from one another. To claim that either one goal leads to the other, or that the two goals are actually the same, may just be intellectual hair-splitting. For Newton, the fact of Reactionary Intercommunalism means that all communities are interconnected. Also, the people of the world taking over the means of production and controlling the social institutions that affect their lives is just another way of saying that the people have selfdetermination. Then, whether one claims that self-determination for the AfricanAmerican community leads to world-wide self-determination, or one claims that selfdetermination for the African-American community is self-determination for everyone does not really matter. What is important is that the goals of the Platform and Intercommunalism do not conflict practically.

Now, there is another way that the Platform and Intercommunalism can be seen to be in tension. Though the beliefs and activities of the Black Panther Party are not inconsistent with how Newton views the world via Intercommunalism, the theoretical basis of the Platform appears to be fundamentally different than the theoretical basis of Intercommunalism.

John McCartney suggests that "Newton's explicitly philosophical comments [... exhibit] the weaknesses of the typical [...] autodidact." (McCartney 1992, 138) So, while "Newton characterizes himself as a dialectician and materialist similar to [Lenin and Mao,] [Newton] is far less systematic than [Lenin and Mao] are in explaining his 
method.” (p. 137) At this point, however, Newton's theoretical shortcomings are far less important than Newton's self-understanding. The important thing to note is that Newton understood his ideology as essentially dialectical. Thus, Newton claimed with Mao Tsetung that:

Correct knowledge can be arrived at only after many repetitions of the process leading from matter to consciousness and then back to matter, that is, leading from practice to knowledge and then back to practice. (Mao 1972, 208-9)

More importantly, besides the integration of theory and practice, matter and consciousness, what Newton took from Mao is that "the phenomenon of contradiction is universal"- I will return to this later. (McCartney 1992, 137) The application of the dialectical method is what led Newton, and the Black Panther Party, from Black Nationalists to Intercommunalists. Therefore, one can reasonably claim that the theoretical basis of Intercommunalism is dialectical.

On the other hand, the Platform — and here I am specifically referring to the Black Panther Party Ten-Point Platform expressing "what we want" and "what we believe"appears to be dogmatic and foundational. While the survival programs developed out of the needs of the people, and Intercommunalism developed out of the application of the dialectical method, the Party Platform was the brain-child of Newton and Seale. Further, while the majority of Newton's ideology changed over time, for all intents and purposes the Party Platform did not. ${ }^{22}$ Moreover, not only was the Party Platform apparently the unalterable personal view of Newton and Seale, and hence dogmatic, but it was also the

\footnotetext{
${ }^{22}$ As was discussed above, Newton did alter the wording of the Ten-Point Platform, but not significantly. More importantly, the Party Platform remained an important part of Newton's and the Black Panther Party's politics even after Newton had settled on Intercommunalism. See footnote 19.
} 
foundational principles that shaped and dominated the Black Panther Party's beliefs and practices.

It has already been suggested that despite Newton's growing awareness of other oppressed communities and his developing ideology, neither he nor the Black Panther Party could completely remove the Black Nationalism, which was present at the Party's inception. Further, though "Newton went door-to-door to find out what the residents needed to sustain a better standard of living [, and orienting] the Black Panther Party's goals to address the concerns conveyed to him by the people in the community," all the survival programs were related to the Party Platform. (Jeffries 2003, 17) Ultimately, there were no survival programs that did not advance some aspect of what Newton and Seale wanted — as professed in the Party Platform.

There are two responses that can be given to the theoretical inconsistency in Newton's thought. First, one could claim that, as Mao contends, "the phenomenon of contradiction is universal." (McCartney 1992, 137) So, the theoretical inconsistencyviz. that Intercommunalism is dialectical, while the Platform is dogmatic and foundational - is just another example of the universal nature of contradiction. In fact, one could go so far as to claim that the existence of the theoretical inconsistency is actually just an example of how the world, including human thought, works when understood dialectically. However, I do not believe that this kind of response is at all adequate. A response like this first one seems to be an intellectual sleight-of-hand. Instead of actually responding to the theoretical inconsistency, the first response merely claims that the inconsistency exists, and then tries to imply that the inconsistency is in fact a virtue. 
The second response one could make to the theoretical inconsistency is to contend that the dogmatic and foundational aspects of the Party Platform are historical/sociological accidents. This second response has two aspects. First, it should be noted that Newton and Seale were members of the African-American community. Not only were they members of the African-American community, but they had been involved actively in the community for many years. Therefore, even though Newton and Seale sat down one day and laid out the Party Platform, it was the result of several years of activism within the African-American community and as members of the AfricanAmerican community. So, it is not the case that the Party Platform is dogmatic in the sense that Newton and Seale arbitrarily put forth certain unalterable principles. The principles came from years of community activism and personal experiences as AfricanAmericans.

Second, during the time in which Newton and the Black Panther Party were active, there were no major changes in the circumstances in either the African-American community or the relationship between the African-American community and American society at large. So, while the survival programs did give the African-American community some semblance of self-determination, help relieve some stresses and pressures on and within the African-American community, and did lead to some noted changes within the larger society, the fact remained that African-Americans were not fairly dealt with by the criminal justice system, and were disproportionately subject to poverty, poor housing, and substandard healthcare. Therefore, it is not the case that Newton and the Black Panther Party dogmatically held to the principles of the Party Platform; it just happens that as a matter of fact the conditions that led to the original 
formulation of the Party Platform had not changed enough to warrant altering the Party Platform significantly.

The fact that the Party Platform was not unalterably dogmatic is further evidenced by the fact that Newton did make changes and modifications to the Party Platform relative to changing circumstances. Though the historical and sociological circumstances of the African-American community did not change during the time the Black Panther Party was active, the ideological circumstances—for lack of a better term-did change. While the changing ideological circumstances did not completely alter the Party Platform, the changing ideological circumstances did affect the Party Platform enough to maintain that Newton was not completely dogmatic about the Party Platform.

The historical/sociological response seems to adequately deal with the problem that the Party Platform is dogmatic. However, the historical/sociological response only begins to cope with the contention that the Party Platform is foundational. It might be that the reason the activities and actions of the Black Panther Party related to, or stemmed from, the Party Platform was just a matter of historical and sociological circumstances. It is just as likely that, because Newton and Seale originally posited "Ten Points" for increasing the self-determination of the African-American community, and maintained them over time, Newton and the Black Panther Party were blinded to other ways that could increase African-American self-determination.

While it has been suggested that there exists a tension in Newton's thought—viz. that the theoretical basis of Intercommunalism is incompatible with the theoretical basis of the Party Platform, there are two ways one could respond to the theoretical inconsistency. Yet, neither response is really adequate. The first response merely 
restates the problem and tries to imply that the theoretical inconsistency is a strength, not a weakness, in Newton's thought. The second response maintains that historical and sociological circumstances affected the Party Platform. The historical/sociological response can overcome the contention that the Party Platform is dogmatic, but only partially deals with the foundational aspect.

Since it appears that there is in fact an inconsistency in Newton's thought, there are three ways that Newton, or one advocating Newton's position, can proceed. First, either Intercommunalism or the Platform must be rejected. Second, one can clearly delineate under what circumstances either Intercommunalism or the Platform should be given primacy. Finally, one can articulate a theory that integrates Intercommunalism and the Platform. While I do think Newton, or the Newtonian, can articulate such a theory, doing so extends beyond the scope of this article.

\section{Conclusion}

In this article, I have sought to explain, and critically engage, some important aspects of Huey P. Newton's political thought. To this end, there was an extended discussion of Newton's developing ideology. However, when considering the actual beliefs and practices of Newton and the Black Panther Party, a tension between Newton's theory of Intercommunalism and the Black Panther Party's Platform and survival programs was identified.

It was shown that there are two ways that the tension could be understood. There is the practical tension inasmuch as the goals of Intercommunalism and the goals of the Party Platform and survival programs seemed to be inconsistent. The practical tension was shown to be only an apparent contradiction. The tension could also be understood to 
be a theoretical contradiction. The theoretical contradiction exists because it seems that the theoretical basis for Intercommunalism-dialectical materialism—is incompatible with the theoretical basis for the Party Platform and survival programs-dogmatic foundationalism.

The semblance of dogmatism in the Party Platform and survival programs is the result of a historical/sociological accident. Because the factors that gave rise to the formulation of the Party Platform and survival programs did not change significantly enough to warrant a radical reformulation of the Party Platform and survival programseven though the survival programs did have an impact on the larger society-the Party Platform and survival programs only appear dogmatic. The foundational aspect of the Party Platform could not be completely dismissed, so the theoretical tension remains.

\section{References}

Abron, J. (1998). "Serving the People": The Survival Programs of The Black Panther Party. In Jones, C. (Ed.), The Black Panther Party Reconsidered (pp. 177-192). Baltimore, MD: Black Classic Press.

Barbour, F. (1968). The Black Power Revolt. Boston, MA: Extending Horizons Books.

Brisbane, R. (1974). Black Activism: Racial Revolution in the United States 1954-1970. Valley Forge, PA: Judson Press.

Erikson, E \& Newton, H. (1973). In Search of Common Ground: Conversations with Erik H. Erikson \& Huey P. Newton. New York: W. W. Norton, Inc.

Heath, L. (1976). The Black Panther Leaders Speak. Metuchen, NJ: Scarecrow Press.

Hilliard, D. \& Weise, D. (2002). The Huey P. Newton Reader. New York: Seven Stories Press.

Hilliard, D, et al. (2006). Huey: Spirit of the Panther. New York: Thunder's Mountain Press. 
Hilliard, D. (2007). The Black Panther: Intercommunal News Service 1967-1980. New York: Atria Books.

Hilliard, D. (2009). The Black Panther Party Service to the People Programs. Albuquerque, NM: University of New Mexico Press.

Jeffries, J. (2003). Huey P. Newton: The Radical Theorist. Jackson, MS: University Press of Mississippi.

Jones, C. (1998). The Black Panther Party Reconsidered. Baltimore, MD: Black Classic Press.

Karenga, M. (1980). Kawaida Theory: An Introductory Outline. Inglewood, CA: Kawaida Publications.

McCartney, J. (1992). Black Power Ideologies: An Essay in African-American Political Thought. Philadelphia: Temple University Press.

Mao T. (1972). Quotations of Chairman Mao Tsetung. Peking: Foreign Languages Press.

Marx, K. \& Engels, F. (1998). The German Ideology: including Theses on Feuerbach and the Introduction to the Critique of Political Economy. Amherst, NY: Prometheus Books.

Muhammad, E. (1974). Our Saviour Has Arrived. Chicago: Muhammad's Temple of Islam No. 2.

Newton, H. (1995). To Die for the People. New York: Writers and Readers Publishing, Inc.

Newton, H. (1996). War Against the Panthers: A Study of Repression in America. New York: Harlem River Press.

Newton, H. (2002). Intercommunalism: February 1971. In Hilliard, D. \& Weise, D. (Eds), The Huey P. Newton Reader (pp. 181-199). New York: Seven Stories Press

Newton, H. (2009). Revolutionary Suicide. New York: Penguin Books.

Pearson, H. (1996). The Shadow of the Panther: Huey Newton and the Price of Black Power in America. Cambridge, MA: Perseus Publishing.

Seale, B. (1991). Seize the Time: The Story of The Black Panther Party and Huey P. Newton. Baltimore, MD: Black Classic Press.

Ture, K. \& Hamilton, C. (1992). Black Power: The Politics of Liberation. New York: Vintage Press. 
